\title{
Suitability of Roselle-Hibiscus sabdariffa L. as Raw Material for Soft Drink Production
}

\author{
Serifat Olatundun Salami $\mathbb{D}^{1,2}$ and Anthony Jide Afolayan $\mathbb{D}^{1}$ \\ ${ }^{1}$ Medicinal Plants and Economic Development (MPED) Research Centre, Department of Botany, University of Fort Hare, \\ Alice 5700, South Africa \\ ${ }^{2}$ Department of Agricultural Education, Federal College of Education (Special), PMB 1089, Oyo, Oyo State, Nigeria
}

Correspondence should be addressed to Anthony Jide Afolayan; aafolayan@ufh.ac.za

Received 25 May 2020; Revised 7 September 2020; Accepted 5 October 2020; Published 30 October 2020

Academic Editor: Daniel Cozzolino

Copyright (c) 2020 Serifat Olatundun Salami and Anthony Jide Afolayan. This is an open access article distributed under the Creative Commons Attribution License, which permits unrestricted use, distribution, and reproduction in any medium, provided the original work is properly cited.

\begin{abstract}
Consumption of conventional soft drinks has been linked with several diseases in man. This has called for the consumption of natural soft drinks such as roselle drink. Roselle-Hibiscus sabdariffa L. is the major raw material for the production of beverage called cranberry (Florida), bissap (Egypt), zobo (Nigeria), and roselle drink generally. The nutritional and phytochemical properties found in roselle make the plant useful in the preparation of some drugs and food. It has been reported that consumption of roselle drink helps to cure diseases such as high blood pressure and diabetes. The pharmacological properties of the plant are traceable to activities of flavonoid and anthocyanin which are the major antioxidants in roselle. Good aroma and colour of the drink are among the characteristics displayed by the plant. However, consumers are sometimes exposed to risks when the drink is consumed after 24 hours of preparation due to the proliferation of spoilage microorganisms in the drink. Most of these microbes thrive even at extreme temperatures. Unfortunately, some of these microorganisms are of public health importance causing diseases such as meningitis and dysentery. Researchers have revealed that roselle calyx is the major source of contamination in the drink. This paper reviews the suitability of the plant for soft drink production. It further highlights the nutrition, pharmacology, and limitations of the plant for soft drink production.
\end{abstract}

\section{Introduction}

Soft drinks refer to nearly all beverages that do not contain a significant amount of alcohol; they are typically carbonated water that do not contain up to $0.5 \%$ of alcohol of the total volume of the drink. According to O'Meara (2007), soft drinks are not so soft because the consumption of the drink has been linked to various ailments that include diabetes, stroke, and obesity. The drinks contain phosphoric acid, malic acid, citric acid, and tartaric acid, which corrode the surface of teeth and cause many dental problems and osteoporosis [1]. These shortcomings can be avoided by taking naturally blended fruit juice or beverages such as roselle drink. Foods and beverages that originated from plants have been reported to be free from saturated fats, sugars, and salts and therefore prevent the build-up of some chronic disease conditions [2]. Roselle drink has been gaining popularity globally as a refreshing medicinal drink. Calyces of Hibiscus sabdariffa, commonly called roselle, are the major raw material for the drink.

Many parts of roselle such as leaves, seeds, flower, and roots are consumed, but the red calyces are the most useful [3]. Roselle calyces are utilized in the production of many food products including beverages, jam, and sauces. Extract of boiled roselle leaves can also be used for beverage production although on rare occasion. Several studies had been carried out on the nutritional and medicinal functions of roselle calyces. Adegunloye et al. (1996) reported that $100 \mathrm{~g}$ of the calyces had $49 \mathrm{~J}$ energy, $84.5 \%$ water, $1.99 \mathrm{mg}$ protein, $0.1 \mathrm{~g}$ fat, $12.3 \mathrm{~g}$ carbohydrate, $2.3 \mathrm{~g}$ fibre, $1.2 \mathrm{~g}$ ash, $1.72 \mathrm{mg}$ calcium, $57 \mathrm{mg}$ phosphorus, $2.9 \mathrm{mg}$ iron, $300 \mu \mathrm{g}$ vitamin A, and $14 \mathrm{mg}$ vitamin C. Wong et al. (2002) found that roselle 
calyces contain a high amount of vitamins (especially vitamin C), carbohydrate, protein, antioxidants, and also minerals. In addition, the extracts of roselle have been reported to contain phytochemicals, vitamins, and several minerals [4].

Despite the increasing popularity of the drink as a result of its health and nutritional benefits, one of the barriers for its preparation in huge quantity is poor shelf life $[5,6]$. The calyces used for the preparation of the drink have been reported to be a major source of contamination as they housed many microbes which spoil foods particularly fungi and bacteria [7]. Other sources of contamination include the unhygienic states of other materials for preparation (such as water, sweeteners and preservatives), the equipment used, packaging materials, the place of preparation, the processors' unhygienic conditions, and poor storage [6]. These sources are, however, reported to give lower contamination when compared with the contamination from calyces [7, 8]. Nwachukwu et al. (2007) reported that Staphylococcus aureus, Escherichia coli, and Pseudomonas aeruginosa are some of the microbes that are mostly found in the drink. The fungi spoil the drink by exuding mycotoxins that are detrimental to human health. This paper reviews the suitability of roselle calyces for the production of soft drink.

\subsection{Uses of Roselle in Different Parts of the World. Almost all} parts of the plants are used for food preparation. The calyces are, however, the most useful [3]. The plant has been used in folk medicines, as a colouring agent, and for beverage or tea preparation. The calyces have been used to produce "Cranberry" in Florida, for liqueurs preparation in Europe for soft drink production in West Africa. In the United States, regulations allow the use of calyces extracts to manufacture alcoholic beverages [9]. The increased rate of consuming the drink is because of its nutrient and medicinal values, as it is cost-effective [10], readily available, and easy to prepare, and also because of its good taste, aroma, and colour. These are inherent features of the plant. At present, millions of people from different social and economic levels in West Africa consume the drink [11] and the drink has become a popular global refreshing drink. Due to the high consumption of the drink, its sale has become a means of livelihood by many women in West Africa.

\subsection{Hibiscus sabdariffa and Its Suitability for Soft Drink} Production. Hibiscus sabdariffa generally known as roselle belongs to the family Malvaceae. The word "roselle" was formed from a girl's name of French origin, which was formed from two words: "rous" meaning red and "elle" meaning she (https://nameberry.com/babyname/Roselle). Roselle is a popular plant in folk medicines, paint manufacture, and beverage production [12]. Roselle calyx is the major raw material used in the production of a beverage called cranberry (Florida), bissap (Egypt, Senegal), and zobo or zoborodo (Nigeria). The nutritional composition of fresh calyces of the plant differs from different studies, probably due to different varieties/genotype, plant environments, and harvesting conditions. Ismail et al. (2008) reported that $100 \mathrm{~g}$ of the calyces gave protein $(1.9 \mathrm{~g})$, fat $(0.1 \mathrm{~g})$, carbohydrates $(12.3 \mathrm{~g})$, and fibre $(2.3 \mathrm{~g})$. The calyces are a good source of ascorbic acid (14 mg), iron (57 mg), and $\beta$-carotene (300 $\mu \mathrm{g})$. This plant is rich in antioxidants [13]. Wong et al. (2002) found roselle to contain high contents of vitamins, protein, carbohydrate, and vitamin C. Furthermore, Babalola et al. (2001) listed the following as nutritional constituents of $100 \mathrm{~g}$ fresh calyces: fats $2.61 \mathrm{~g}$, fibre $12.0 \mathrm{~g}$, ash $6.9 \mathrm{~g}$, calciun $12.63 \mathrm{mg}$, protein $1.145 \mathrm{~g}$, phosphorus $2732 \mathrm{mg}$, iron $8.98 \mathrm{mg}$, carotene $0.029 \mathrm{mg}$, niacin $3.765 \mathrm{mg}$, thiamine $0.117 \mathrm{mg}$, ascorbic acid $1.7 \mathrm{mg}$, and riboflavin $0.277 \mathrm{mg}$. Many reports confirmed that the calyx is loaded with a high content of calcium, niacin, riboflavin, iron, and vitamin $\mathrm{C}$ (9× stronger than an orange) [14]. The United State Department of Agriculture reported that $100 \mathrm{~g}$ of calyces contain $11.31 \mathrm{~g}$ of carbohydrate, $0.64 \mathrm{~g}$ of fat, and $0.96 \mathrm{~g}$ of protein. Similarly, roselle has been reported to contain biological active chemical substances that have curative properties. Eggernsperger et al. (1996) reported that the major bioactive constituents of the calyces that have a pharmacological function are flavonoids, organic acids, anthocyanin, and polysaccharides. The phytochemicals in roselle calyces according to [4] contained flavonoids $20.08 \%$, tannins $17.00 \%$, saponins $0.96 \%$, phenols $1.10 \%$, alkaloids $2.14 \%$, and glycosides $0.132 \%$, which must have given it its pharmacological properties. Extract of calyces has been reported to reduce the viscosity of the blood; it also has antimicrobial, diuretic, febrifugal, antihypertensive, and antihelminthic properties $[15,16]$.

Similarly, earlier studies demonstrated that roselle calyces contain high contents of anthocyanin and phenolic compounds. Anthocyanins are a group of plant pigments that are responsible for the attractive colours of many fruits and flowers including calyces of red roselle [17]. Six anthocyanins are common in fruits and vegetables; these are pelargonidin, cyanidin, delphinidin, malvidin, peonidin, and petunidin [18]. Anthocyanins are important quality indicators in plants. Research reports have shown that anthocyanin has many medicinal benefits, among which are antioxidant [19, 20], anticarcinogenic [21], antimicrobial [22], anti-inflammatory [20, 23], cardioprotective [20, 24], and hepatoprotective [25] properties. To provide support to our body defence mechanism, our diet must contain a sufficient amount of nutrients and antioxidants. Incorporation of antioxidant-rich foods in our daily diet boosts our immune system and it is safer and cheaper than commercially available antioxidants. Accumulation of free radicals in the body leads to oxidative stress, which is linked to several diseases in the body and can even cause death [26, 27]. Antioxidants are compounds, which inhibit the rate of oxidation of molecules in the body through the obstruction of the multiplication of the chain reaction of free radicals. Natural antioxidants are better than the synthetic ones as they usually have nutraceutical properties [28]. Roselle is one of the plants that have been reported to contain various types of antioxidants in huge amount and, hence, possess high pharmacological properties [29]. The red calyces contain antioxidants including hibiscetine, gossypetin, and sabdaretine while cyanidin 3-sambubioside and delphinidin 3- 
sambubioside are the major anthocyanin present. Roselle calyces also have $4 \%$ citric acid, amino acid organic acids, and minerals. The plant is popular in folk medicine for its laxative, antibacterial, and diuretic properties and because of its high vitamin $\mathrm{C}$ content; it is used for the treatment of scurvy, cold, or flu [30]. This plant is commonly used in herbal medicines in Africa, India, and Mexico. Extracts of the leaves or calyces are traditionally used for their diuretic and hypotensive effects and also decreasing the viscosity of the blood and stimulating intestinal peristalsis [31]. It is also useful in the treatment of cardiac and nerve diseases, cancer, and liver toxicity. Apart from nutritional and medicinal qualities, important features of the plant that make it suitable for soft drink preparation include the following:

(i) The plant has a good aroma, taste, flavour, and attractive colour

(ii) Little quantity of the calyces is used to produce litres of soft drink ( $100 \mathrm{~g}$ of calyces is used to produce 4 or more litters of hibiscus tea)

(iii) It is easy to prepare, and the production cost is low and materials and equipment for processing the drink are well available and cheap

(iv) Its preparation does not require a high skill

(v) Most importantly, the plant is safe to consume [32]

(vi) It thrives in tropical and subtropical parts of the worlds and even in some temperate countries making it more available

Shoemaker et al. (2005) opined that medicinal plants are a major source of bioactive compounds that are useful in disease prevention. Herbal medicines are cost-effective and have a mild side effect on the body.

Furthermore, roselle drink (Sorrel, zoborodo) is a nonalcoholic nutritive beverage made from different parts of the plant, particularly the dried calyces [7,33-36]. Roselle drink has become a household drink with daily consumption in many countries such as Egypt, Mexico, and Nigeria [37]. Most of these countries have specific names for the drink for examples, cranberry in Florida, Kumbang in Malaysia, Karcade in Sudan, bissap in Egypt and Senegal, and zobo or zoborodo in Nigeria. Because of health problems associated with alcoholic drinks, roselle drink has potential as a cheap substitute to red wines and alcoholic beverages in general [34]. The demand for the drink is mainly because of its nutritive value, aroma, flavour, and colour [36]. Researchers have found that roselle drink contains a significant amount of ascorbic acid in addition to $2.61 \mathrm{~g}$ of fat, $12.0 \mathrm{~g}$ of fibre, $1.145 \mathrm{~g}$ of protein, $273.2 \mathrm{mg}$ of phosphorus, $8.98 \mathrm{mg}$ of iron, $1,263 \mathrm{mg}$ of calcium, $0.029 \mathrm{mg}$ of carotene, $0.117 \mathrm{mg}$ of thiamine, $3.765 \mathrm{~m}$ of niacin, and $0.277 \mathrm{mg}$ of riboflavin. Currently, there are various studies on the nutritional composition of the drink; for example, Olayemi et al. (2011) gave the nutritional composition of the drink made from dark red, bright red, and wine varieties to contain 0.0875 , 0.0875 , and $0.04375 \mathrm{ppm}$ of protein, respectively, while vitamins were $7.5,5.0$, and $5.0 \mathrm{mgg}^{-1}$, respectively. The drink also contains vitamins, natural carbohydrates, protein,

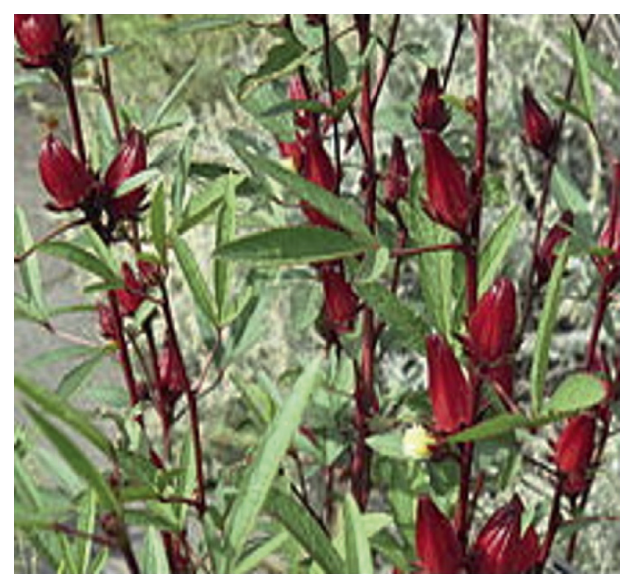

Figure 1: Roselle-Hibiscus sabdariffa L.

calcium, iron, etc. [38, 39]. Similarly, the phytochemical analysis of the drink showed that it contains anthocyanin, glycosides, alkaloids, tannins, polyphenols and saponins, sterols, and phenols $[40,41]$. It also contains vitamin E, polyphenolic acids, and flavonoids, mainly anthocyanins [42]. Okoro (2003) reported that the drink contains about $15-30 \%$ organic acids like citric acid, tartaric acid, and malic acid; also, it contains acidic polysaccharides and flavonoid glycosides such as cyanidin and delphinine, which are effective in the treatment of several ailments. All these qualities were inherited from the calyces used for the preparation.

1.3. Health Benefits and Safety of Roselle Drink. The drink has been reported to have antioxidant [43], antihypertensive [44], antihypolipidaemic [45], anticancer [46], antibacterial [47], hepatoprotective and antistress [48], antidiuretic [49], antispasmodic [50], and antidiarrheal [51] activities. Another study found that the drink affects metabolism, thereby preventing obesity and fat build-up in the liver. Roselle has generally been considered safe as a foodstuff; dosage of $1.5 \mathrm{~g}$ is recommended for daily consumption [52]. The safety profile of roselle is excellent, with no proven adverse reactions. Noteworthy, Hudson (2013) affirmed that, for reducing cholesterol level, studies recommend 1,000 mg dried herb 3 times daily; 1 cup of the drink two times daily, or $100 \mathrm{mg}$ of standardized extract twice daily and also for hypertension 1 cup of the drink twice daily or dried powdered roselle extract providing $250 \mathrm{mg}$ anthocyanin per day was recommended.

1.4. Preparation of Roselle Drink. Roselle drink is prepared in several ways using varieties of ingredients, the dried calyces being the major ingredient for preparing the drink (Figures 1 and 2). All the methods result into the drink but with a little different taste (based on the sweeteners used such as sugar, honey, pineapple juice, sugar cane, and maple syrup) and flavour based on the spices used. Selection of preservatives and flavour for the drink depends on individuals. Some of these preservatives include garlic and ginger [8], lime $[8,12,53]$, clove, cinnamon, and nutmeg, and pepper fruit [54]. More recently, other plant materials are added as a 


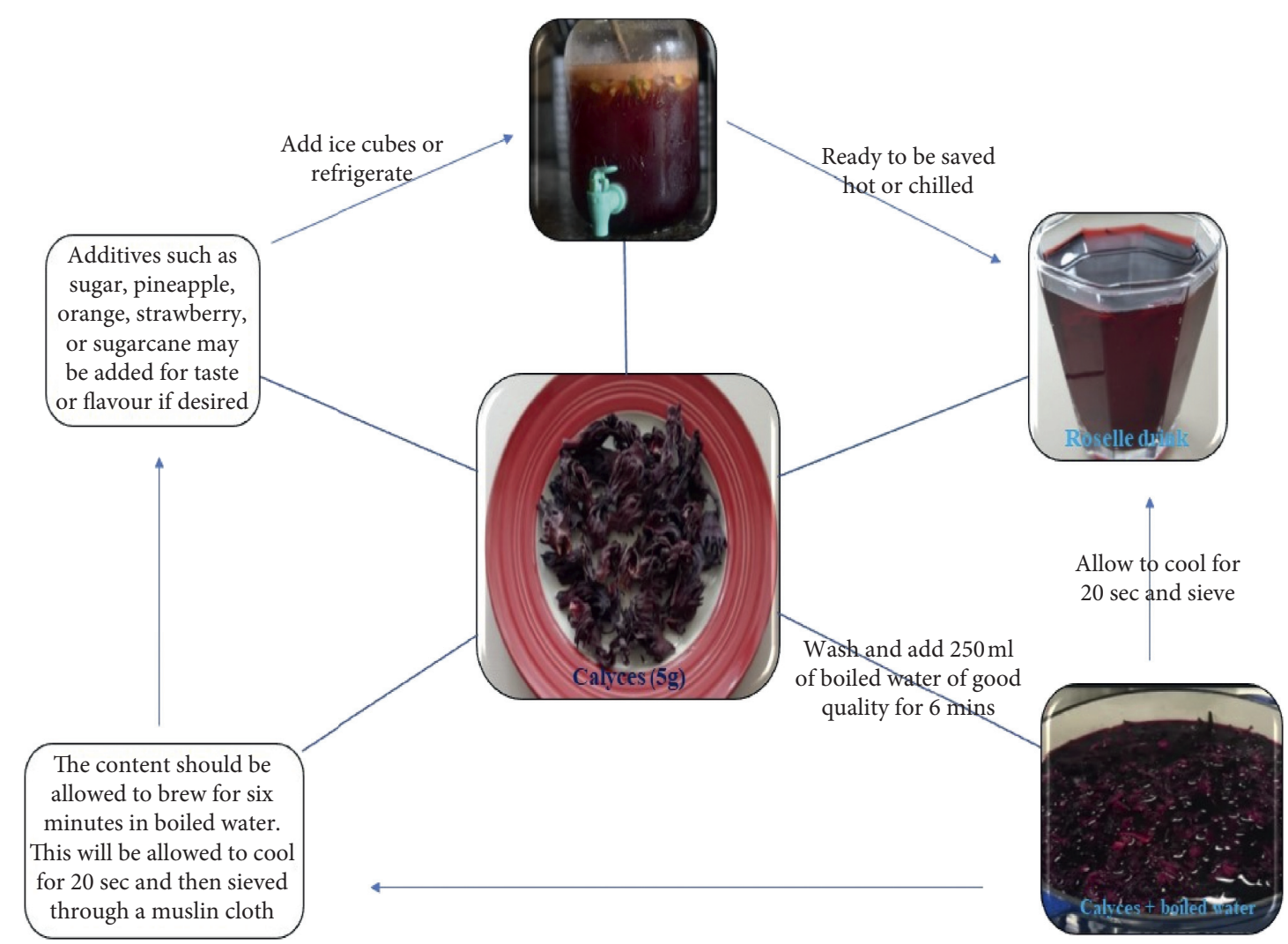

FIGURE 2: An international organization for standardization (ISO 3103) procedure for producing the tea from calyces.

blend in the preparation of the drink to enhance the flavour and keeping qualities. The infusion of roselle calyces is usually sweetened with fruit juice, sugar cane, or granulated sugar or pineapple, depending on preference $[12,35,53]$. Straw berry is another additive used in the preparation of the drink [34]. Although the drink has different names all over the world, the flavour is very similar usually having a tangy flavour profile. There are two main methods of preparing the drinks: the steeping and boiling using different procedures. Generally, the steeping method is carried out by pouring boiled water into clean calyces inside a bowl and set aside for two to four hours. The juice is then separated from the calyces using sieve; fruit juice and sweeteners are then added based on preference. The drink can be taken hot or cold. The boiling method, on the other hand, is carried out by putting clean calyces with sliced fruits pineapple, oranges, and lime (with peel) (based on individuals) into a clean pot, covered with water, and boiled for five minutes, and then the desired spices were added such as cinnamon, garlic, and ginger. More water is added to the content and then left to boil for 30 minutes. The juice is then collected from the content using sieve and sweeteners added if desired. The drink is refrigerated afterwards and served chilled.

Egbere et al. (2007), however, prepared the drink in the laboratory as follows:

(i) One hundred grams of the dried calyces was sorted out and rinsed under tap water (ii) The calyces were ground in a sterile laboratory blender to obtain a paste

(iii) Two litres of warm sterile water $\left(\right.$ at $\left.60^{\circ} \mathrm{C}\right)$ was added to the paste and left for 1 hour to enable extraction

(iv) The mixture was then filtered through a muslin cloth and then flavoured with $200 \mathrm{~g}$ of sugar and strawberry or any fruit juice to taste

There are other reports on laboratory preparation of the drink. For examples, Umaru et al. (2014) prepared the drink by hurling the dried calyces into the water, leave for $1-2$ hours and then sieve after cooling. Some researchers, Nwachukwu et al. (2007) and Ezeigbo et al., (2015) have severally reported a stricter soaking period of 10-15 minutes. Then, preservatives (such as ginger, clove, and garlic) and sugar are added before cooling $[7,53]$. The resultant filtrate is then consumed as hot tea or taken like a refreshing drink when chilled [12]. Bolade et al. (2009) gave the following reports on hibiscus beverage preparation: the dried calyces/ water ratios used in the commercial practice were in the range of $1: 57$ to $1: 71(\mathrm{w} / \mathrm{v})$, and the sweetness level of the beverage was in the range of 11.2 to $13.3^{\circ}$ Brix; the appropriate dried calyces/water ratio for commercial roselle drink production was found to be $1: 62(\mathrm{w} / \mathrm{v})$ while the extraction period was 30 minutes at a constant temperature of $100^{\circ} \pm 2^{\circ} \mathrm{C}$. The indices for assessing the quality of the drink were found to be taste, colour intensity, and sweetness level. Similarly, the International Organization for Standardization has specified procedures for producing the tea 
by means of infusing the calyces (Figure 2). "Shandy Sorrel" produced in Trinidad and Tobago is a combination of roselle drink and beer. The drink is one of the common beverages consumed in Mexico and Central America. In the Middle East and Sudan, "Karkade" calyces are steeped or boiled for about one hour. Mint leaves, menthol, fruit juice, and sweeteners are added to make the drink especially in social events. In West Africa, the refreshing drink is prepared by leaving the calyces in the water overnight or boiling for about an hour, sieving, and then adding juice and sweeteners for good taste.

1.5. Limitations of Roselle Juice as a Global Drink. Despite its medicinal and nutritional values, the drink does not have good keeping quality because of contamination. Roselle drink is reported to contain enteropathogenic microorganisms up to $2.49 \times 104 \mathrm{CFU} / \mathrm{ml}$. This is hazardous to the consumers especially when a large volume of the drink is taken $[55,56]$. The drink is rich in phytonutrients and minerals which could give room for the multiplication of the microorganisms. The microbial diversity found in the drink is mainly bacteria and fungi. Although microorganisms in food are not always detrimental, in fact at a time, their growth may result in pleasant taste and texture [56]. However, microorganisms such as Pseudomonas aeruginosa, Staphylococcus aureus, Salmonella, E. coli, Vibrio cholerae, Bacillus, and Clostridium species if present could contaminate food and cause diseases to the consumers of the drink [56]. Some of the microorganisms commonly found in roselle drink areStaphylococcus aureus, Escherichia coli, and Pseudomonas aeruginosa [53]. Also, Ezeigbo et al. (2015) reported that the microbes that have been widely isolated from the drink sold in public places in Nigeria belong to the genera Streptococci, Staphylococci, Escherichia, Salmonella, Shigella, Enterobacter, Klebsiella, Serratia, Bacillus, Lactobacilli, Clostridium, Proteus, Pseudomonas Corynebacterium, Micrococcus, and Aeromonas (bacteria); Saccharomyces, Aspergillus, Penicillin, Fusarium, Candida, Rhizopus, Geotrichum, and Mucor (fungi). Different species of Aspergillus toxigenic fungi have been associated with the drink as reported [5, 57]. Ilondu and Iloh (2007) found A. flavus and A. Niger in roselle drink. Aflatoxin produced by some Aspergillus species has been reported to be carcinogenic, teratogenic, and mutagenic to several species of experimental animals [58]. The aflatoxin is highly carcinogenic and can cause liver diseases [59]. Some of these microorganisms (e.g.,Bacillus spp.) can withstand high temperature; thus boiling cannot eliminate them. Aflatoxin is heat-stable with a melting point of 268 to $269^{\circ} \mathrm{C}$ [60]; thus subjecting it to high temperature does not reduce its effects. Also, most of the organisms can withstand refrigerating conditions particularly bacteria; thereby it becomes difficult to eliminate them using a cold treatment. Thus, the best bet is for the drink not to get contaminated at all. Food borne microbes may be pathogenic and/or reduce the quality of the drink in terms of colour, taste, aroma, and nutrition. Most of the fungal contaminants can spoil the drink and can introduce mycotoxins which are harmful to man. The occurrence of coliforms in the drink portends a potential risk to consumers; this is because coliforms in the drink exceeding the permissible recommended limit of zero (0) in ready-to-eat food are an indication of contamination [61]. Coliforms such as E. coli are known to cause varying degree of gastroenteritis depending on the strain. The presence of $E$. coli and $E$. aerogenes usually signifies the presence of fecal materials in the drinks and suggests the presence of other enteric pathogens [36]. Similarly, Bacillus has been isolated from roselle drink [7]. The spores of Bacillus spp. can withstand high temperatures during processing. Contrarily, some of the microbial species are mesophilic and thus can withstand very low temperatures and can cause spoilage even at refrigeration temperatures [7]. Hence, the refrigerated roselle drink often has high bacteria load.

1.6. Sources of Contamination of Roselle Drink. There are various sources of contamination of roselle drink; the main ones are the calyces used, the processing environment including the method of preparation, water and types of equipment used for the preparation of the drink, the packaging material, and conditions of preservation and storage as discussed below.

1.7. The Roselle Calyces Used. The calyces have been reported to get infested with microorganisms through the seed stock used, local growing conditions, and postharvest handling especially during drying and storage and in the market. Studies confirm that the bulk of contamination of the drink is through the calyces used as a major raw material. The high content of water in fresh calyces predisposes the calyces to infection; even if the calyces are later dried some of the microorganisms remain. At the local market, roselle calyces are displayed in big containers (uncovered) or polyethene sheets for sale; these expose calyces to microbial contamination [62]. The presence of contaminants and toxigenic fungi from roselle drink is a function of contamination of the calyces used $[7,63]$. These authors $[7,63]$ reported that total bacteria counts, coliform counts, and total fungi counts were in the range of $5.0-13.0 \times 103,0.00-<102 / \mathrm{g}$, and 3.4-7.3 $\times 104 \mathrm{CFU} / g$, respectively, from dried $H$. sabdariffa calyces sold in a different market in Uyo, Akwa Ibom State, Nigeria. The microbial counts in the zobo drinks sold in the markets and hawked in streets ranged from $10^{2}$ to $10^{8} \mathrm{CFU} /$ $\mathrm{ml}$. These values depend on the type of flavour, preservatives used, and storage duration. For instance, bacteria counts of $8.1 \times 104 \mathrm{CFU} / \mathrm{ml}, \quad 1.21 \times 105 \mathrm{CFU} / \mathrm{ml}, \quad 2.6 \times 105 \mathrm{CFU} / \mathrm{ml}$, $3.2 \times 105 \mathrm{CFU} / \mathrm{ml}$, and $2.5 \times 106 \mathrm{CFU} / \mathrm{ml}$ were for zobo drink prepared without sugar, with sugar, with no sugary spices, with sugary spices, and with sugary spices + pineapple flavour, respectively [64]. Majority of the microbes found in the samples caused spoilage. Also, B. subtilis, S. aureus, S. fecalis, L. brevis, P. putida, A. niger, A. flavus, S. cerevisiae, $P$. citrinus, $R$. oligosporus, C. krusei, and Mucor sp. are microbial isolates found in the dried roselle calyces sold in some market in Ogun State, Nigeria [5]. The associated bacteria were Bacillus subtilis, Bacillus sp., Enterococcus faecalis, Micrococcus sp., Klebsiella sp., and Staphylococcus 
aureus. The fungi isolates were Aspergillus flavus, A. terreus, A. glaucus, P. expansum, Fusarium oxysporum, and Cladosporium. Aspergillus glaucus was the dominant species among the six species. Odunfa (1998) reported that Staphylococcus aureus levels of $108 / \mathrm{mL}$ were considered potentially hazardous to consumers. The main fungi associated with roselle calyces were Aspergillus spp. This may be due to the presence of their spores in a large number in the atmosphere which can easily settle on the harvested calyces in the farm, during processing, or in the market. It has been made clear that most contamination of the drink was as a result of contamination of the calyces; this implies that some of the calyces presently offered for sale in our markets are not acceptable for the production of the drink for human consumption [63]. Although during processing the calyces are often subjected to high temperature, once the raw materials are contaminated, it becomes difficult to get rid of all microorganisms through boiling; for example, boiling aflatoxin does not reduce its potency [60].

1.8. Contamination during Preparation. Water is another raw material for the preparation of the drink. The quality of water also determines the quality of the drink [65]. Clean and sterile water is good for a quality drink as poor water introduces some microbes that are dangerous to health. Other materials used such as sweeteners (sugar, sugar cane juice, and pineapple juice), preservative materials such as garlic, lime, ginger, and benzoic acid as well as equipment such as bowls, pots, and stirrer used during preparation are possible means of contamination. Risiquat (2013) reported that contamination may occur when the hot extract is left to cool, during the introduction of flavour and sweeteners and bottling. The place of preparation if not hygienic can be a source of contamination. In addition, the level of hygiene of the processor and the activities of the handlers such as cleaning children after defecating, cleaning mucus, sneezing, coughing, and excessive talking can be means of introducing toxigenic microbes into the drink. Akhigbemidu et al. (2015) affirmed that Streptococci spp. which are often found in the mouth enter the drink during preparations via talking.

1.9. Contamination during Packaging. In developing countries, the drink is locally packaged by the use of polyethene sachet/films and plastic bottles. These materials if already polluted can contaminate the drink. Majority of the processors of the drink in the developing countries are small-scale women and even some children who may not attach more importance to hygiene. Due to ignorance and poverty level of some processors, used bottles are reused for packaging; if such bottles were not thoroughly washed, it can cause contamination of the drink. Besides, some processors use mouth to blow air into polyethene sachets to open them; this is a means of introducing microorganisms into the drink. All other unhygienic activities like singing during packaging can cause contamination. Staphylococcus spp. and Pseudomonas spp. may occur in the drink due to handling and other utensils used after processing [7].
1.10. Contamination during Storage. Conditions of a place of storage and duration of storage can also encourage contamination. If the storage environment is unhygienic or favourable for microbes' multiplication, contamination can occur. The values of microbial counts depend on the type of flavour, preservatives used, and storage duration [62]. Nevertheless, Risiquat (2013) found that the microbial population of the drink seldom exceeds acceptable/level and tolerant level for ready-to-eat food the day it is prepared.

\subsection{Precaution for Roselle Drink Quality and Durability}

1.11.1. Proper Handling. If calyces are produced, packaged, and sold in aseptic conditions, contamination of the drink will be minimal. Growers and processors of crops as well as market women should be educated on how to handle their crops especially roselle calyces to prevent contaminations. Thus, harvesting must be carefully done to reduce contamination. Mohammed et al. (2012) reported that harvesting while raining can downgrade the quality of the calyces and lower the output. Calyces should be handled properly to avoid contact with the ground or filthy surfaces. Since calyces contamination has been cited as the major point of contamination [7,63], having sterile calyces will ensure high durability and better quality drink. Incidence of aflatoxin in dried calyces' samples can be avoided through proper handling, adequate storage facilities, and planting of Aspergillus spp. resistant varieties.

1.11.2. Avoidance of Contamination during Preparation and Packaging. The drink should be prepared in hygienic environments and all materials and equipment used should be sterile. Activities that will cause contamination such as talking, sneezing, and scratching of the body should be avoided or minimized by the use of mouth and nose guard and overall dress to serve as a precaution. Also, to avoid contamination, the drink should be aseptically poured into sterilized polythene sachets and then sealed back using a thermoelectric sealing machine. Furthermore, thorough boiling should be encouraged to kill the heat susceptible microbes that may be in the drink. The drink is mainly prepared through boiling and steeping; however, steeping does not give much heat influence on the microbes in the drink. So steeping method of preparation should be discouraged.

1.11.3. Preservation. The following preservation methods could be used to prevent or reduce contamination:

Physical preservation: this is the preservation of materials or substance through pasteurization, freezing, and refrigeration. Pasteurization is done when the bottled drink is immersed in sterile water, heated to $70^{\circ} \mathrm{C}$ or more, and left for 20 minutes. Egbere et al. (2007) recommended a combination of pasteurization and sodium benzoate to extend the shelf life of the drink to forty days. Freezing and refrigeration are achieved by subjecting the microorganisms present in 
the drink to a very low temperature to make them inactive and prevent their multiplication. Nevertheless, these cannot affect microbes that thrive in freezing temperature. Besides, the electricity supply is not adequate in some developing countries.

Chemical preservation: this is carried out by the use of chemical preservatives. Preservatives are chemical additives that are used to improve the keeping qualities of food products to prevent or reduce the microorganism growth and sustain the chemical quality of the food such as colour, taste, aroma, and texture [66]. Chemical preservatives commonly utilized in the preparation of the drink are acetic acid and sodium benzoate, although sorbate and propionate can also be used. Acetic acid has been reported to have a superior effect on bacteria than sodium benzoate and vice versa for fungi [8]. Doughari et al. (2007) reported that benzoic acid-treated samples sustained the taste until after 14 days of storage. The use of chemicals can reduce the qualities of the drink and can be harmful to consumers of the drink. Studies have shown that the use of synthetic chemical for food preservation could have adverse effects on human health. Thus, acetic acid produced from biomass through a microbial method such as oxidative fermentation was recommended as the best for food preservation [62]l this can be used to elongate the shelf life of this nutritious drink.

Biological method of preservation: this refers to the use of plant extracts especially spices to preserve; those spices used include lime, ginger, garlic, pepper fruit, and kola nut. Natural spices have been commonly used as food additives and for improving flavour [67]. Lime can reduce the microbial load of the drink; this may be due to its acidic nature [53]. Acidic foods inhibit the survival of many pathogens but enhance the multiplication of acidic organisms, hence the domination of Bacillus spp., Lactobacillus spp., and S. cerevisiae in the drink [34]. The acidity of lime is organic and less corrosive to the alimentary canal [8]. Braide et al. (2012) further reported that lime was effective in suppressing microbial load than garlic, ginger, and glove even better than sodium benzoate. Although both ginger and garlic have antimicrobial effects, a mixture of ginger and garlic is more effective than when used separately $[68,69]$. Izah et al. (2015) found that the ability of natural preservatives to eliminate microorganisms is in the following order: lime $>$ mixture of garlic and ginger $>$ ginger $>$ garlic $>$ clove $>$ kola nut $>$ cinnamon $>$ nutmeg. These authors recommended the use of these natural preservatives to enhance the quality of the drink and to reduce spoilage.

\section{Conclusion}

Roselle is a suitable ingredient for soft drink production because all the desirable qualities of the drink in terms of nutrition, appearance, and medicinal qualities were inherited from the plant. Since the calyces have been discovered to be the major source of contamination of the drink that causes its low shelf life, all the precautions to ensure aseptic conditions of the calyces must be adopted. The plant production, calyces, and drink processing and marketing need to be overhauled and monitored to be fit for human consumption. Thus, if sterile calyces are used and the drink is prepared under the aseptic condition, there will be little or no contamination and the drink will have higher keeping quality and thus exhibit the perfect suitability of the plant. Although contamination can also occur through other routes as stated above, this is to a lesser extent. In addition, preservatives can be added to lengthen the shelf life of the drink, prevent microbial build-up, and improve the taste, flavour, and nutritional and medicinal value of the drink.

\section{Data Availability}

No data were used to support this study. All literature were cited accordingly.

\section{Conflicts of Interest}

The authors declare no conflicts of interest.

\section{Acknowledgments}

The authors appreciate the financial support of Govan Mbeki Research and Development Centre (GMRDC), University of Fort Hare, South Africa, under Grant no. C127.

\section{References}

[1] J. A. Hughes, N. X. West, D. M. Parker, M. H. Van Den Braak, and M. Addy, "Effects of $\mathrm{pH}$ and concentrations of citric, malic and lactic acids on enamel, in vitro," Journal of Dentistry, vol. 28, no. 12, pp. 47-52, 2000.

[2] T. C. S. P. Pires, L. Barros, C. Santos-Buelga, and I. C. F. R. Ferreira, "Edible flowers: emerging components in the diet," Trends in Food Science \& Technology, vol. 93, pp. 244-258, 2019.

[3] Q. Yadong, K. Chin, F. Malekian, M. Behane, and J. Gajer, "Biological characteristics, nutritional and medicinal value of roselle, Hibiscus sabdariffa," Urban Forestry Natural Resources and Environment Circular, no. 604, p. 2, 2005.

[4] C. N. Okereke, F. C. Iroka, and M. O. Chukwuma, "Phytochemical analysis and medicinal uses of Hibiscus sabdariffa," International Journal of Herbal Medicine, vol. 2, no. 6, pp. 16-19, 2015.

[5] A. M. Omemu, M. O. Edema, A. O. Atayese, and A. O. Obadina, "A survey of the microflora of Hibiscus sabdariffa (Roselle) and the resulting "Zobo" juice," African Journal of Biotechnology, vol. 5, no. 3, pp. 254-259, 2006.

[6] O. E. Nwafor and M. J. Ikerebomeh, "Effects of sodium benzoate on the growth and enzyme activity of Aspergillus niger and Penicilium citrimon on Zobo drink during storage," African Journal of Health Technology, vol. 8, no. 12, pp. 2843-2847, 2009.

[7] N. A. Amusa, O. A. Ashaye, A. A. Aiyegbayo, M. O. Oladapo, M. O. Oni, and O. O. Afolabi, "Microbiological and nutritional quality of hawked sorrel drinks (soborodo) (the Nigerian locally brewed soft drinks) widely consumed and 
notable drinks in Nigeria," Journal of Food Agriculture and Environment, vol. 3, no. 3, pp. 47-50, 2005.

[8] W. Braide, I. J. Odiong, and S. U. Oranusi, "Phytochemical and antibacterial properties of the seed of watermelon (Citrullus lanatus)," Prime Journal of Microbiology Research (PJMR), vol. 2, no. 3, pp. 99-104, 2012.

[9] International Organization for Standardization, ISO 3103: 2019 Tea-Preparation of Liquor for Use in Sensory Tests, International Organization for Standardization, Geneva, Switzerland, 2019, https://www.iso.org/standard/73224.html.

[10] V. H. Shruthi and C. T. Ramachandra, "Roselle (Hibiscus sabdariffa L.) calyces: a potential source of natural color and its health benefits," Food Bioactives: Functionality and Applications in Human Health, pp. 169-190, 2019.

[11] I. S. Ogiehor and O. E. Nwafor, "Associated microbiological, biochemical and chemical quality changes in zobo beverage produced from Hibiscus sabdariffa Linn," Nigerian Annals of Natural Sciences, vol. 5, pp. 1-10, 2004.

[12] O. Ezeigbo, M. Ekaiko, N. Agomo, K. Ojukwu, and A. Nnadozie, "Antimicrobial effect of lime juice treatment on the shelf-life of Zobo drink," British Microbiology Research Journal, vol. 6, no. 3, pp. 147-153, 2015.

[13] M. G. L. Hertog, E. J. M. Feskens, D. Kromhout et al., "Dietary antioxidant flavonoids and risk of coronary heart disease: the Zutphen elderly study," The Lancet, vol. 342, no. 8878, pp. 1007-1011, 1993.

[14] I. Amin, E. K. I. Hainda, and S. M. N. Halimatul, "Roselle (Hibiscus sabdariffa L.) seeds nutritional composition, protein quality and health benefits," Foods, vol. 2, no. 1, pp. 1-16, 2008.

[15] F. Delgado-Vargas and O. Paredes-Lopez, "Natural colorants for food and nutraceutical uses," CRC Press. LLC, Boca Raton, FL, USA, 2002.

[16] N. W. Desrosier, The Technology of Food Preservation, Vol. 4, AVI Publishing Company, West Port Connecticut, 1970.

[17] Y.-L. Wu, S. B. Hooks, T. K. Harden, and H. G. Dohlman, "Dominant-negative inhibition of pheromone receptor signaling by a single point mutation in the G protein $\alpha$ subunit," Journal of Biological Chemistry, vol. 279, no. 34, pp. 3528735297, 2004.

[18] L. C. Kerio, F. N. Wachira, J. K. Wanyoko, and M. K. Rotich, "Characterization of anthocyanins in Kenyan teas: extraction and identification," Food Chemistry, vol. 131, no. 1, pp. 31-38, 2012.

[19] B. Yousuf, K. Gul, A. A. Wani, and P. Singh, "Health benefits of anthocyanins and their encapsulation for potential use in food systems: a review," Critical Reviews in Food Science and Nutrition, vol. 56, no. 13, pp. 2223-2230, 2016.

[20] B. Salehi, J. Sharifi-Rad, F. Cappellini et al., "The therapeutic potential of anthocyanins: current approaches based on their molecular mechanism of action," Frontiers in Pharmacology, vol. 11, pp. 1-20, 2020.

[21] W.-C. Lee, C.-J. Wang, Y.-H. Chen et al., "Polyphenol extracts from Hibiscus sabdariffa Linnaeus attenuate nephropathy in experimental type 1 diabetes," Journal of Agricultural and Food Chemistry, vol. 57, no. 6, pp. 2206-2210, 2009.

[22] P. Viskelis, M. Rubinskienè, I. Jasutienè, A. Šarkinas, R. Daubaras, and L. Česoniene, “Anthocyanins, antioxidative, and antimicrobial properties of American cranberry (vaccinium macrocarponAit.) and their press cakes," Journal of Food Science, vol. 74, no. 2, pp. C157-C161, 2009.

[23] A. B. Meraiyebu, O. T. Olaniyan, C. Eneze, Y. D. Anjorin, and J. B. Dare, "Anti-inflammatory activity of methanolic extract of Hibiscus sabdariffa on carrageenan induced inflammation in Wistar rat," International Journal of Pharmaceutical Science Invention, vol. 2, no. 3, pp. 22-24, 2013.

[24] D. Ojeda, E. Jiménez-Ferrer, A. Zamilpa, A. Herrera-Arellano, J. Tortoriello, and L. Alvarez, "Inhibition of angiotensin convertin enzyme (ACE) activity by the anthocyanins delphinidin- and cyanidin-3-O-sambubiosides from Hibiscus sabdariffa," Journal of Ethnopharmacology, vol. 127, no. 1, pp. 7-10, 2010.

[25] A. Ologundudu, A. O. Ologundudu, I. A. Ololade, and F. O. Obi, "The effect of Hibiscus anthocyanins on 2, 4dinitrophenylhydrazine-induced hepatotoxicity in rabbits," International Journal of Physical Sciences, vol. 4, no. 4, pp. 233-237, 2009.

[26] M. O. Jimoh, A. J. Afolayan, and F. B. Lewu, "Antioxidant and phytochemical activities of Amaranthus caudatus L. harvested from different soils at various growth stages," Scientific Reports, vol. 9, no. 1, pp. 1-14, 2019.

[27] M. O. Jimoh, A. J. Afolayan, and F. B. Lewu, "Nutrients and Antinutrient constituents of Amaranthus caudatus L. cultivated on different soils," Saudi Journal of Biological Sciences, 2020, in press.

[28] I. Mourtzinos, D. P. Makris, K. Yannakopoulou, N. Kalogeropoulos, I. Michali, and V. T. Karathanos, "Thermal stability of anthocyanin extract of Hibiscus sabdariffa L. In the presence of $\beta$-cyclodextrin," Journal of Agricultural and Food Chemistry, vol. 56, no. 21, pp. 10303-10310, 2008.

[29] F. J. Alarcon-Aguilar, A. Zamilpa, M. D. Perez-Garcia et al., "Effect of Hibiscus sabdariffa on obesity in MSG mice," Journal of Ethnopharmacology, vol. 114, no. 1, pp. 66-71, 2007.

[30] N. C. McClintock and I. M. E. Tahir, "Hibiscus sabdariffa L," in Vegetables/Legumes, G. J. H. Grubben and O. A. Denton, Eds., PROTA, Wageningen, Netherlands, 2004.

[31] J. F. Morton, Roselle Fruits of Warm Climates, Creative Resource Systems, Inc., Miami, FL, USA, 1987.

[32] US Department of Agriculture, Food Safety \& Inspection Service, US Department of Agriculture, Washington, DC, USA, 2008, http://www.fsis.usda.gov.

[33] S. B. Fasoyiro, O. A. Ashaye, A. Adeola, and F. O. Samuel, "Chemical and storability of fruit-flavoured (Hibiscus sabdariffa) drinks," World Journal of Agricultural Sciences, vol. 1, no. 2, pp. 165-168, 2005.

[34] O. J. Egbere, J. C. Anuonye, P. F. Chollom, and P. V. Okpara, "Effects of some preservation techniques on the quality and storage stability of zobo drink (a Nigerian, non-alcoholic beverage from Hibiscus sabdariffa)," Journal of Food Technology, vol. 5, no. 3, pp. 225-228, 2007.

[35] A. R. Saraswati, D. Mardiah, and D. Taniwiryono, "Formulation of ready to drink (rtd) made from roselle (Hibiscus sabdariffa. L) tea and stevia (stevia rebaudiana) leaf safe for diabetics," Indonesian Journal of Applied Research (IJAR), vol. 1, no. 1, pp. 1-9, 2020.

[36] G. A. Umaru, I. S. Tukur, U. A. Akensire et al., "Microflora of kunnu-zaki and sobo drinks in relation to public health in Jalingo metropolis North-Eastern. Nigeria," International Journal of Food Research, vol. 1, pp. 16-21, 2014.

[37] A. A. Abou-Arab, F. M. Abu-Salem, and E. A. Abou-Arab, "Physico-chemical properties of natural pigments (anthocyanin) extracted from Roselle calyces (Hibiscus subdariffa)," Journal of American Science, vol. 7, no. 7, pp. 445-456, 2011.

[38] P. Wong, Y. Salmah, H. M. Ghazali, and Y. B. Che Man, "Physico-chemical characteristics of roselle (Hibiscus sabdariffa L.)," Nutrition and Food Science, vol. 32, no. 20, pp. 68-73, 2002. 
[39] S. O. Babalola, A. O. Babalola, and O. C. Aworh, "Compositional attributes of the calyces of Roselle (Hibiscus sabdariffa L)," African Journal of Food Technology, vol. 6, no. 4, pp. 133-134, 2001.

[40] O. Bola and O. O. Aboaba, "Microbiological and physicochemical evaluation of some non-alcoholic beverages," Pakistan Journal of Nutrition, vol. 3, no. 3, pp. 188-192, 2004.

[41] P. F. Builders, C. R. Ezeobi, F. D. Tarfa, and M. I. Builders, "Assessment of the intrinsic and stability properties of the freeze-dried and formulated extract of Hibiscus sabdariffa Linn. (Malvaceae)," African Journal of Pharmacy and Pharmacology, vol. 4, no. 6, pp. 304-313, 2010.

[42] S. Cid-Ortega and J. A. Guerrero-Beltran, "Roselle calyces particle size effect on the physicochemical and phytochemicals characteristics," Journal of Food Research, vol. 3, no. 5, pp. 83-94, 2014.

[43] V. Hirunpanich, A. Utaipat, N. P. Morales et al., "Antioxidant effects of aqueous extracts from dried calyx of Hibiscus sabdariffa Linn. (Roselle) in vitro using rat low-density lipoprotein (LDL)," Biological \& Pharmaceutical Bulletin, vol. 28, no. 3, pp. 481-484, 2005.

[44] A. Herrera-Arellano, J. Miranda-Sánchez, and P. Avila-Castro, "Clinical effects produced by a standardized herbal medicinal product of Hibiscus sabdariffa on patients with hypertension. a randomized, double-blind, lisinopril-controlled clinical trial," Planta Medica, vol. 73, no. 1, pp. 6-12, 2007.

[45] C.-C. Chen, J.-D. Hsu, S.-F. Wang et al., "Hibiscus sabdariffa extract inhibits the development of atherosclerosis in cholesterol-fed rabbits," Journal of Agricultural and Food Chemistry, vol. 51, no. 18, pp. 5472-5477, 2003.

[46] H.-H. Lin, H.-P. Huang, C.-C. Huang, J.-H. Chen, and C.-J. Wang, "Hibiscus polyphenol-rich extract induces apoptosis in human gastric carcinoma cells via p53 phosphorylation and p38 MAPK/FasL cascade pathway," Molecular Carcinogenesis, vol. 43, no. 2, pp. 86-99, 2005.

[47] E. E. Abdallah, "Antibacterial efficiency of the Sudanese Roselle (Hibiscus sabdariffa L.), a famous beverage from Sudanese folk medicine," Journal of Intercultural EthnoPharmacology, vol. 5, no. 2, p. 186, 2010.

[48] B. H. Ali, N. A. Wabel, and G. Blunden, "Phytochemical, pharmacological and toxicological aspects of Hibiscus sabdariffa L.: a review," Phytotherapy Research: An International Journal Devoted to Pharmacological and Toxicological Evaluation of Natural Product Derivatives, vol. 19, no. 5, pp. 369-375, 2009.

[49] F. B. O. Mojiminiyi, B. J. Adegunloye, Y. A. Egbeniyi, and R. V. Okolo, "An investigation of the diuretic effect of an aqeuos extracts of the calyx of Hibiscus saddariffa," Fitoterapin, vol. 78, no. 4, pp. 292-297, 2000.

[50] M. B. Ali, W. M. Salih, A. H. Mohamed, and A. M. Homeida, "Investigation of the antispasmodic potential of Hibiscus sabdariffa calyces," Journal of Ethnopharmacology, vol. 31, no. 2, pp. 249-257, 1991.

[51] A. M. Salah, J. Gathumbi, and W. Vierling, "Inhibition of intestinal motility by methanol extracts of Hibiscus sabdariffa L. (Malvaceae) in rats," Phytotherapy Research, vol. 16, no. 3, pp. 283-285, 2002.

[52] Wolters Kluwer Health, http://www.drug.com/ Hibiscus: benefits, uses and effects accessed on, 2006.

[53] E. Nwachukwu, O. M. Onovo, and C. F. Ezeama, "Effect of limejuice on the bacterial quality of Zobo drinks locally produced in Nigeria," Research Journal of Microbiology, vol. 2, no. 10, pp. 787-790, 2007.
[54] A. Ihemeje, M. C. Ojinuala, K. C. Obi, and C. C. Ekwe, "Biochemical evaluation of pepper fruit (Dennettia tripetala) and its use as substitute for ginger in zobo drink production," Academic Research International, vol. 4, no. 6, pp. 513-521, 2013.

[55] E. M. Foster, "Interpretation of analytical result for bacterial standards enforcement," Association of Food and Drug, pp. 543-548, 2003.

[56] A. Bukar, A. Uba, and T. A. Oyeyi, "Occurrence of some entropathogenic bacteria in some minimally and fully processed read-to-eat foods in Kano metropolis, Nigeria," African Journal of Food Science, vol. 4, no. 2, pp. 32-36, 2010.

[57] E. M. Ilondu and A. C. Iloh, "Inhibition of three fungal isolates from sorrel drink (Zobo) using hurdle technique," World Journal of Agricultural Sciences, vol. 3, no. 3, pp. 339-343, 2007.

[58] W. H. Butler and J. M. Barnes, "Carcinogenic action of groundnut meal containing aflatoxin in rats," Food and Cosmetics Toxicology, vol. 6, no. 2, pp. 135-141, 1968.

[59] D. L. Eaton and J. D. Groopman, Eds., Human Health, Veterinary, and Agricultural Significance, pp. 383-426, Academic Press, New York, NY, USA, 1st edition, 2013.

[60] S. Mohammed, K. Shehu, and N. A. Amusa, "Survey of the market diseases and aflatoxin contamination of tomato (Lycopersicum esculentus Mill) fruits in Sokoto, NorthWestern Nigeria," Nutrition and Food Science, vol. 34, no. 2, pp. 72-76, 2006.

[61] R. O. Risiquat, "Bacteriology quality of zobo drinks consumed in some parts of Osun State, Nigeria," Journal of Applied Sciences and Environmental Management, vol. 17, no. 1, pp. 113-117, 2013.

[62] S. C. Izah, L. A. Orutugu, and L. T. Kigigha, "A review of the quality assessment of zobo drink consumed in Nigeria," ASIO Journal of Microbiology, Food Science and Biotechnology Innovations, vol. 1, no. 1, pp. 34-44, 2015.

[63] B. C. Adebayo-Tayo and U. A. Samuel, "Microbial quality and proximate composition of dried Hibiscus sabdariffa calyces in Uyo, Eastern Nigeria," Malaysian Journal of Microbiology, vol. 5, no. 1, pp. 13-18, 2009.

[64] E. I. Seiyaboh, I. Y. Oku, and O. M. Odogbo, "Bacteriological spoilage of zobo (A Nigerian drink prepared from the calyces of Hibiscus sabdariffa L.) Malvaceae," The International Journal of Engineering and Science, vol. 2, no. 11, pp. 46-51, 2013.

[65] M. K. Bolade, I. B. Oluwalana, and O. Ojo, "Commercial practice of roselle (Hibiscus sabdariffa L.) beverage production: optimization of hot water extraction and sweetness level," World Journal of Agricultural Sciences, vol. 5, no. 1, pp. 126-131, 2009.

[66] Y. O. Bankole, A. O. Tanimola, R. O. Odunnukan, and D. O. Samuel, "Preservation of zobo drink (calyces of Hibiscus sabdariffa) using kolanut," Academic Journal of Interdisciplinary Studies, vol. 2, no. 10, pp. 17-23, 2013.

[67] I. M. Omoruyi and O. T. Emefo, "In vitro evaluation of the anti biogramic activities of seeds of Mystica fragrans on food borne pathogens," Malaysia Journal of Microbiology, vol. 8, no. 4, pp. 253-258, 2012.

[68] I. A, I. P. Abiola, M. O. Adigun, and O. A. Anifowose, "Analysis of quality attributes of Hibiscus sabdariffa (zobo) drinks blended with aqueous extract of ginger and garlic," African Journal of Food Science, vol. 7, no. 7, pp. 174-177, 2013.

[69] F. Mahomoodally, S. Ramcharun, and G. Zengin, "Onion and garlic extracts potentiate the efficacy of conventional antibiotics against standard and clinical bacterial isolates," Current Topics in Medicinal Chemistry, vol. 18, no. 9, pp. 787-796, 2018. 